\title{
The Decline of Centralized Collective Wage Bargaining in Sweden
}

\author{
Karel Hanuš $\check{1}^{12}$ \\ Katedra sociologie, FF UK v Praze, Praha \\ The Decline of Centralized Collective Wage Bargaining in Sweden. This \\ article explores development (including its shaping in the 1930s and \\ institutionalisation within the Post-war economic model) and causes of the decline \\ of centralized collective wage bargaining in Sweden. Some effects of the Post-war \\ model in combination with changes in global economic environment and \\ technology of production caused changes in domestic distribution of power and \\ influenced strategies and institutional preferences of crucial actors (especially the \\ association of the export-oriented engineering employers, but also unions). The \\ way of connection of the Swedish and the global economy is therefore of \\ fundamental importance for shaping of domestic socioeconomic institutions like \\ collective bargaining.
}

Key words: collective bargaining, wage policy, employers, unions, Sweden

Rozpad centralizovaného kolektívneho vyjednávania o mzdách vo Švédsku. Tento článek zkoumá vývoj (včetně formování ve 30. letech institucionalizace $\checkmark$ rámci poválečného ekonomického modelu) a přičiny rozpadu centralizovaného kolektivního vyjednávání ve Švédsku. Některé důsledky poválečného ekonomického modelu $v$ kombinaci se změnami $v$ globálním ekonomickém prostředí a technologii výroby způsobily změny $v$ rozdělení moci a ovlivnily strategie a institucionální preference klíčových aktérů (zvláště asociace exportně orientovaných zaměstnavatelů ve strojírenství, ale i odborů). Způsob propojení švédské a globální ekonomiky má tedy zásadní význam pro formování domácích socioekonomických institucí typu kolektivního vyjednávání.

Klíčová slova: kolektivní vyjednávání, mzdová politika, zaměstnavatelé, odbory, Švédsko

\section{Introduction}

The system of centralized collective wage bargaining was one of the key features of the Swedish economic model. It was a way, how to make a compromise between interests of employers and employees, especially in the export sector, that could be compatible both with competitiveness and

\footnotetext{
${ }^{1}$ In this place, I would like to acknowledge the helpful comments of Prof. Jürgen Kohl.

${ }^{2}$ Address: PhDr. Mgr. Karel Hanuš, Katedra sociologie, Filozofická fakulta Univerzity Karlovy, Celetná 20, 11642 Praha 1, Česká republika. Tel: +420 221619680, fax: +420 221619686; hanusk@email.cz
}

Slovak Journal of Political Sciences, Volume 14, 2014, No. 1 
economic growth and with socio-political goals of the labor movement (solidarity and equality). Institutionalization as well as decline of the system was influenced, on the one hand, by the structure of the Swedish economy and its connection to the global capitalist economy and, on the other hand, by strategy and power of the crucial actors like employers association, trade unions and state. In this draft I would like to present a sketch of causes and course of the decline of centralized wage bargaining in Sweden in the 1980s and early 1990s. Concretely, to explain strategies and power coalitions of the different actors within changing economic and political environment that lead to creation, institutionalisation and dismantling of the system (i.e. the different institutional preferences in solving similar problems). It had an impact in many fields, not only in economic policy, but also in labor market and employment policy, distribution of power or ideological climate. It raises also a question, what theoretical approach is more suitable and fruitful for explanation of different and changing institutional preferences of the crucial actors in reaction to similar problems under different circumstances. Analysing of the development of the centralized wage bargaining system in Sweden contributes not only to explanation of working of the Swedish economic model, but in general perspective also to debates on possibilities and limits of the different types of centralized bargaining in the global capitalist economy.

\section{Roots of centralized collective bargaining in Sweden}

Historically, the Swedish economy has always been very open and export oriented. Different conditions for companies and also for their employees in the export sector (especially engineering sector) and sheltered domestic sector (particularly construction) caused during the interwar period a growing wage disproportion in favour of construction workers who had stronger positions for advocating their wage demands. It attracted workers from the engineering sector or agriculture to construction; so the engineering employers strived to control intersectoral wage structure especially in favour of the export sector. With using lockouts and "multisector solidarity" (i.e. multiindustry lockouts) they pressured the other employers associations (and in cross-class coalition as well as resisting trade unions) to accept centralization of bargaining. The institutionalization of the centralized bargain system led to the domination of the employers and trade unions confederations over their membership associations and through control of opponents it served for solving conflicts of interests both between and within classes. Other consequences of this policy were also moderation of wages especially in construction and partial loss of bargaining autonomy of the construction workers unions, but also protection of rural jobs and promise of new jobs in construction due to a new anti-crisis housing plan. The coalition between labor and capital also helped in the 1930s 
to create of a new parliamentary coalition of farmers and workers. (Swenson, 1991).

Using this explanation, Peter Swenson criticizes the left mobilization thesis (held for example by Walter Korpi (1983)) for assumption that power mobilisation of the social democratic party and strong trade unions pressed weak and passive capital to defence. In fact, social democrats and unions held power not against the will or at the expense of the employers, but with quiet coalition with dominant group of employers (for example, social democrats quite generously compensated employer's lockouts). This cross-class coalition is also one of the possible explanations of the long-term domination of social democrats, because due to the compromise there was not such a strong opposition of capital against social democratic policy (in comparison with other countries). This domination began in 1932, when social democrats won parliamentary elections and thereby gained a possibility to implement their vision of the People's Home (Folkhemmet), based on ideas of political, social and economic democracy.

However, as Walter Korpi (2006) pointed out, Swensons' explanation is based on a wrong interpretation of the power resources approach and, more importantly, his explanation is separated from its historical context. Result of the 1932 elections changed political climate and distribution of power in Sweden - economic power was still held by capital, but political power by social democrats and unions. It caused a shift of feasible political alternatives towards the Left and therefore decreasing of historical disadvantage of labor. In this situation, for employers it was more suitable not to openly support the bourgeois parties - nevertheless, they continued still in a financial and organisational support for the Conservative and the Liberal Party, conservative press and periodical mobilisation against Social Democratic policy. That means that employers preferred collaboration with the bourgeois parties rather than with the Social Democratic Party and therefore rather "a tacit cross-class coalition" (as Swenson put in) there was a periodically intensive class-related conflict not always, but often with positive-sum results.

Under changed circumstances, there was a new wave of industrial conflicts and bargaining that ended with a conclusion of a "historical compromise“ between labor and capital in Saltsjöbaden in 1938. A core of the agreement was a commitment to maintenance of employers' control over investments and production, their acceptance of broader welfare policy, general support of economic growth and industrial peace based on bargaining between employers and unions without direct state interference. (Korpi, 1983) It was also an important milestone in the development of centralized bargaining the institutionalization of which was result of conflicts and coalitions both between 
and across classes. It would have not been possible without extensive uniting of employers' and workers' organisation in all sectors of the Swedish economy.

\section{The post-war economic model and solidaristic wage policy}

The interwar „historical compromise“ between labor and capital meant the creation of a base for post-war centralized bargaining (f.e. establishing of the detailed procedures for collective bargaining). At first, the LO was reluctant to take active role in wage bargaining and the centralization of bargaining was imposed rather by the employers and the government and only in the $60 \mathrm{~s}$ became the LO fully committed to bargaining with the SAF (Pontusson, 1987, p. 483). During the first post-war decade, until 1955, bargaining was focused primarily on wages, but most of it took place at industry level. Since 1956 all bargaining rounds between the Swedish employers association (SAF) and blue collar trade unions (LO) took place at the national level and covered most of blue collar workers in the private sector. Agreements on the central level set the tariff wages, but they were implemented and sometimes distorted through bargaining on the industry and firm level. Local bargaining set trend for the wage drifts that amounts around half of overall wage increase. Centralized wage bargaining between the SAF and the LO ran without direct state intervention, but government influenced it indirectly: government can offer tax reductions in exchange for wage demands moderation, special relationship between social democratic party and the LO makes it sometimes easier and sometimes more difficult to moderate wage demands, government as an employer in the public sector can influence bargaining strategies if unions can suppose that unemployment can be compensated by expansion of the public sector, government can also have a role of mediator in bargaining, unions also have possibility in advocacy of their demands to choose between collective bargaining and legislative means. (Elster, 2013, p. 182, 190-191) This ,golden period" of the centralized wage bargaining in Sweden lasted until 1983; since then the degree of confederation involvement began to oscillate, and after ten years this system was finally dismantled.

During the "golden period" the system of centralized wage bargaining became one of the key parts of the so called Rehn-Meidner model. This new model of economic policy, proposed in 1955 by LO economists Gøsta Rehn and Rudolf Meidner (who also convinced initially reluctant LO prominents that solidaristic wage policy would have been beneficial for labor movement as a whole (Pontusson, 1987, p. 483-484)), was based on a few basic principles. First, it was an active role of the state in investment and planning (for example, a plan for building one million new flats during the sixties). Second, a solidaristic wage policy, based on the principle "same job = same wage“" (i.e. wage differentials should reflect differences between different kinds of work, 
but not between different productivity of employers) and agreements between the SAF and the LO. Third, motivation for investments, increasing of productivity and rationalisation of production (see Figure 1.), because due to equalisation of wages the less efficient firms were forced to rationalise their production to be able to manage wage costs or to go bankrupt and the most efficient companies were able to accumulate more capital, to invest more and to expand. Fourth, one of the main goals of social democratic policy was full employment. Therefore government carried out an active employment policy, among others to compensate unemployment caused by the impact of wage policy on the least efficient firms.

Figure 1: Consequences of wage policy for firms with different ability to pay wages

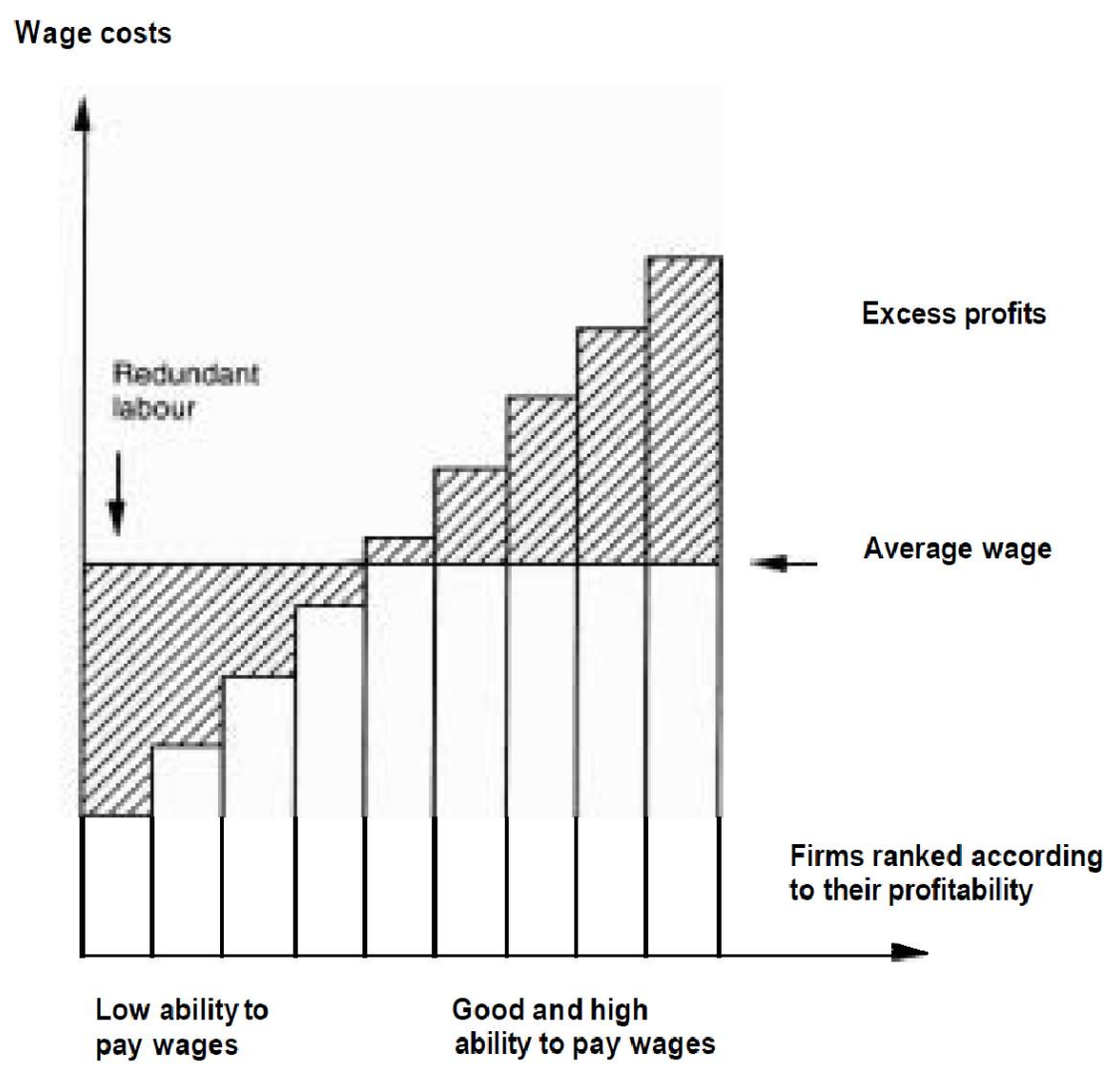

Source: (Meidner, 1993, p. 218) 
Fifth, restrictive fiscal policy served as prevention of high national debt and, in combination with moderation of wages, also as a prevention of inflation. Sixth, it was generous welfare policy with universal coverage that compensated moderation of wages for workers. Seventh, an important precondition and instrument for implementing this policy was state control of monetary and credit markets, for example by using of state pension funds for loans with low interest. Politically, this system was realized under the uninterrupted government of social democracy (see Appendix A) (for example (Stephens, 1997), (Magnusson, 2000), (Meidner, 1993)).

The Rehn-Meidner economic model had for almost two decades impressive economic results: through restructuration of industry growth of productivity and competitiveness, economic growth, full employment, small national debt and low inflation. Other effects of this model were also low degree of social inequalities, concentration of production, consensus and relative depoliticization of employers. Solidaristic wage policy was particularly beneficial for people with low paid jobs, but also for the biggest firms. A combination of solidaristic wage policy with other policies (housing program, agricultural regulations etc.) contributed to the great expansion and concentration of production under control of a relatively small, but powerful part of the Swedish capitalist class. However, the domestic market is too small and limited for these big corporations, so they tended to expand abroad. For example, if we take a ranking of the world top 500 industrial corporations in 1975 - 1990, the Swedish industrial corporations were with respect to size of the Swedish population very successful (see Table 1).

Table 1: Nationality breakdown of the world top $\mathbf{5 0 0}$ industrial corporations

\begin{tabular}{|l|l|l|l|l|}
\hline & 1975 & 1980 & 1985 & 1990 \\
\hline Sweden & 13 & 10 & 6 & 17 \\
\hline UK & 49 & 51 & 48 & 43 \\
France & 29 & 29 & 23 & 30 \\
Germany & 38 & 38 & 33 & 30 \\
\hline Japan & 54 & 66 & 82 & 111 \\
USA & 241 & 217 & 212 & 164 \\
\hline
\end{tabular}

Source: adapted from (Ikeda, 1996, p. 75)

That is manifestation both of the high competitiveness of Swedish corporations and a comparatively high concentration of production. 


\section{The proposal of wage earners fund}

Nevertheless, the increasing concentration of ownership was in Swedish society viewed as a problem - not only by the socialist parties (preferring collective ownership), but even by some bourgeois parties (preferring individual shareholders). Concentration of ownership became one of political issues during the post'68 „red wave“ period (Ryner, 2006). Radicalisation of Swedish politics towards the Left was manifested in the most visible way in a new labor legislation, making stronger workers' influence at the workplace (introduced through parliament, although usually these issues were solved by centralized bargaining without any direct state intervention) and especially in case of a wage earners fund proposal. This proposal, designed by the main LO economist Meidner and his team, was originally intended as a solution of three problems: to reduce concentration of ownership, compensation for excessive profits (moderation of wages in the most profitable companies, because of the absence of wage pressures by unions, enabled excessive profits for owners) and to increase the influence of workers at the workplace (i.e. economic democracy). An original version of the proposal involved an idea of taxation of excessive profits in favour of special funds administered by boards dominated by unions. Financial resources within these funds were to be used for reinvestment within the companies and in this way for increasing the share of collective ownership.

The wage earners fund proposal was accepted by the LO delegates with enthusiasm and had a vitalizing effect on the labor movement (Meidner, 1993), but social democrats were very reluctant in its support, because their leaders were afraid of propaganda by non-socialist parties and employers that might scare many voters. So, in the campaign before 1976 parliamentary elections, they remained with traditional welfare policy, but their allies from the LO shifted more towards ownership policy. (Lewin, 1988) Not surprisingly, the wage earners fund proposal was sharply rejected by employers and bourgeois parties who warned against „collectivization of Sweden“. Despite its primary intent, it was viewed as an anti-capitalist reform - both by employers and bourgeois parties and also by many union members. The SAF viewed it as a break with the historical compromise of Saltsjöbaden and started an intensive ideological campaign against the wage earners fund proposal within the theoretical framework of just emerging neoliberalism, establishing neoliberal think tanks, promoting educational and political seminars, supporting ambitious young bourgeois politicians (like the future Prime minister Carl Bildt) and with the help of the Swedish Central Bank using the prestigious Nobel Prize for awarding of neoliberal economists. (Harvey, 2007) This campaign contributed to the defeat of Social democrats in the 1976 elections, and they had to be in 
opposition for the next six years. Finally, wage earners funds were introduced after the elections of 1982, but in a very limited and rather symbolical version.

\section{Changes in the global capitalist economy}

The three post-war decades were a period of global economic growth, rise of international trade, productivity, innovations, full employment (for males) and are sometimes called as "the golden period" of welfare state. However, this situation changed during the next decade, i.e. the 1980s. The industrial growth based on the homogenized mass production was brought closer to its limits; it led to a decline of economic growth, productivity and traditional industries and caused structural unemployment and deindustrialization in many developed countries. External factors like the oil crisis and the breakdown of the BrettonWoods system contributed to waves of "stagflation" (combination of stagnation and inflation) and financialization of capitalism (Foster, Magdoff, 2009, p. 77). Unlike of the interwar period (characterized by a commercial, but not financial regulation), and of the post-war period (characterized by a financial, but not commercial regulation), there was now both financial and commercial deregulation.

These factors caused a situation, in which traditional recipes of Keynesian policy became inefficient, which opened space for other approaches (i.e. monetarism and neoliberalism). Deregulation of the economy also contributed to the internationalisation of economy and the rise of multinational (MNCs) and transnational corporations (TNCs). In politics, this period (following after penetration of the mainstream by radical ideas), was distinguished by a series of defeats of the Left forces (for example, the original version of the wage earners fund proposal in Sweden, the Carnation revolution in Portugal, the original economic program of François Mitterand in France or the government of Unidad Popular in Chile) and rise of the New Right, neoliberalism and neoconservatism, especially in the Anglo-Saxon countries.

In the sphere of production, the most important changes were the gradual transition from the Fordist standardized mass production to the Post-Fordist more customized mass production with more added value, based more on knowledge and innovations (stimulated by new methods, like teamwork). However, the new production strategies and development towards flexibilization were in contradiction with the solidaristic wage policy that was designed for homogenised mass production. As Rudolf Meidner admitted (1993, p. 221-222), the LO was not enough prepared for these changes. It had an impact especially in the export oriented engineering sector, where came up erosion of lines between blue and white collar workers and the partial individualisation of wages in form of wage drifts undermined the wage moderation effects of solidaristic policy. 


\section{Internationalisation of the Swedish economy}

The Swedish post-war economic model was based on the compromise between interests of labor (solidarity, equality, welfare policy, full employment) and capital, especially big companies had advantages in terms of tax policy and wage policy (moderation of wages, see above), labor market institutions or weak antitrust legislation. However, the Swedish domestic market is rather limited, so the biggest Swedish companies tended to expand abroad, in the early 1980s to the USA, and after 1985 even more into the united European market. An increasing degree of internationalisation of the Swedish MNCs, especially in sphere of production, led to the decline of their domestic operations and had contraction effects on the Swedish economy. Since the 1970s the country's share in world export decreased, but the Swedish MNCs, dominating the country's export, dramatically increased export via its foreign branches.

Changes in the European market contributed to the restructuration of the Swedish MNCs that led to a situation when their domestic production became focused more on goods with fewer added values and their foreign production became more knowledge intensive. Weaker connections of the Swedish MNCs with the domestic economy became part of a general trend of moving industrial capacities from peripheral countries to the European centre that later became one of the reasons for joining the EU. (Andersson, Fredriksson, Svensson, 1996)

Due to the internationalisation and Post-Fordist flexibilization of production, for the MNCs, especially in the engineering industry, local regulation, domestic demand, wage policy and price stability became less important. Wage flexibility became instrument of managerial control (for support of creation more skilled and loyal workers) and the current wage bargaining system was viewed as an obstacle. The diminishing importance of Sweden as a base of development of export products caused decreasing need of the MNCs for a regulation system enabling to combine effective domestic demand and price stability. Internationalisation of production made also problem with labor shortage less pressing through expansion of capital to the areas with high unemployment. These companies became more high profit oriented (high profits important for improving debt to equity ratio to sustain firm-specific expenditures on research and development), tended to support devaluation (under changed circumstances probably seen as a better defence of competitiveness than income policies), higher unemployment (by demands for elimination of macroeconomic instruments of full employment policy) and a stronger role of financial markets as well (expansion of money and the stock market leading to more market-mediated financial system and thus probably 
more market oriented preferences of capital). (Ryner, 2006, p. 146-147) In this way, the Swedish MNCs gained a stronger position in local bargaining and could afford to realize more aggressive bargaining strategies.

\section{State policy and changes in union structure}

During the period of the bourgeois governments in 1976 - 1982, there were no significant changes in economic and social policy, because of strong unions and lack of support by the public. After 1982, a new social democratic government decided to implement a "Third Way" economic policy - a compromise between socialist/Keynesian policy of Mitterand and neoliberal policy of Margaret Thatcher (at first the government moved back to the traditional social democratic policy like before radicalisation, but during the key year 1985 it embraced neoliberal elements (Ryner, 2006)). The second Olof Palme government $(1982-1986)$ reacted to above mentioned tendencies of rising of structural unemployment by way of public sector expansion, especially in the social service sector (typically part-time jobs for women). On the one hand, this policy contributed to a comparatively high level of female employment; on the other hand, such a policy is relatively expensive and was financed by increasing taxation and national debt. Expansion of the public sector entailed changes for working of the Swedish model: since the solidaristic wage policy was fully compatible or even facilitating for the private sector employment growth in the period of concentration of the employment potential in the most dynamic industry sectors, since the 1960s the highest potential for employment expansion was in the service sector and therefore the only way how to maintain full employment within the Rehn-Meidner model in postindustrialized economy was expansion of the public service sector. (Iversen 1999, p. 171-172)

Expansion of the public sector in combination with Post-Fordism and a gradual emerging post-industrial economy gave rise to the strengthening of the white collar unions (TCO) and the professional unions (SACO). The LO was still the strongest union association, but lost part of its previous power position. Unlike the other unions, the LO was closely connected with the Social Democratic party (SAP) (until 1987 all LO members were automatically collective members of the SAP) and supported solidaristic wage policy. However, despite generally good relations between the three union associations, the other two more politically neutral ones preferred different strategies. The main difference was that the LO demanded solidarity with low income workers, but the TCO and the SACO did not, and consequently the LO had more limited bargaining possibilities. Moreover, the wage drift practice undermined the moderation effects of the solidaristic wage policy and the unity of the labor movement. ((Meidner, 1993), (Galenson, 1998)) Increasing 
taxation also weakened the willingness of individual workers to accept unionist moderation wage policy, so the next governments offered reduction of taxes in corporatist exchange for acceptance of wage moderation (crucial elements of the wage bargaining agreements in 1974 and Rosenbad bargaining in 1984). (Mares, 2006)

The Swedish government reacted to the decreasing share of national exports in overall world export by efforts to increase rentability of the Swedish companies by forced devaluation (1982) and financial deregulation, especially of credit markets (1985). These measures had immediate, but temporary effects (higher rentability led to stronger wage pressures, but it was realized only in form of wage drifts). At the end of the 1980s, however, the Swedish economy experienced overheating, high inflation and over-employment. High wage increases in the sheltered domestic sector (especially in the public sector and construction) in combination with only moderate ones in the manufacturing industry contributed to a lack of skilled workers in the export engineering sector. The short-term economic boom during the 1980s undermined the "Third Way" strategy and the ability to defend against employer's demands to decentralize wage bargaining (Martin, 2000).

\section{The Swedish employers' offensive against centralized bargaining}

As mentioned above, since the mid1970s there was in Sweden intensive political and ideological conflict because of the wage earners fund proposal by the LO and the SAP. The SAF reacted to it by establishing think-tanks, organizing seminars and publishing „scientific“ analyses, where welfare state, corporatism, regulations, centralized bargaining, solidaristic wage policy and taxation were presented as causes of contemporary problems, and also by providing support to some bourgeois politicians and parties. This way the SAF contributed to a neoliberal shift within the bourgeois parties and disseminating of neoliberal ideas in the Swedish society.

The main mover in the offensive against centralized wage bargaining was the engineering employers association (VF). Its confrontation strategy during the 1970s failed because of its isolation within the SAF and lack of public and governmental support, so it decided for a strategy of undermining its institutional base. In 1983, the VF made a separate contract with the metalworkers union (Metall), offering them more than they would otherwise have gotten within centralized agreement. However, the separate agreement was criticized both by the LO and by the SAF. During the next seven years the wage bargaining and agreements oscillated between decentralized and centralized negotiations. Because of the employers' offensive and radicalisation of the political climate, it was much more difficult to make a 
compromise, so bargaining in this period was moderated and influenced by government much more than in the past.

In 1990, the SAF dissolved its bargaining and statistical department and one year later withdrew from almost all governmental bargaining boards. The withdrawal coincided with the economic crisis and the social democratic government created the so called Rehnberg commission with representatives of the SAF, the LO, the TCO and the SACO for setting a temporary two-years centralized agreement. However, after two years a new bourgeois government with Carl Bildt as a Prime minister refused to renew this kind of centralized bargaining and this marked the end of the peak-level centralized wage bargaining in Sweden. The SAF was therefore no more oriented towards centralized bargaining and its new role included political lobbying and influencing public opinion towards rejection of the social democratic policy (via think tanks and mass medias) and information and consultation services for employers and their sectoral associations. Nevertheless, bargaining continued on industry level, and there were still obvious effects of institutional path dependency, for example in case of labor market regulations (Tsahouras, 2008), but, as Lindvall and Sebring (2005) point out, many previously existing elements of corporatism disappeared - not only the formal ones, but also informal norms and practices which could be explained by a fact, that the norms of social partnership, on which was corporatism depended, were damaged by comparatively high politisation of bargaining.

The aims and strategy of the VF are shaped by its economic interests (production, wage competition etc.), but the reactions to similar problems may differ over time - earlier it preferred centralisation and now decentralisation. In the 1930s, the main goal of the centralisation of collective bargaining was moderation of wages in domestic sector, especially construction, because its dynamics and increasing wage demands of well organized labor caused too strong wage pressures in the export sector (see above). In the 1970s and 1980s, the main goal of decentralisation was to increase wage differentials between the export and the sheltered domestic sector (in favour of the former one) to attract more skilled workers, strengthen their firm loyalty and stimulate innovations (generally, to be able to use wages as an instrument of managerial control).

In the 1970s the VF reacted to new "institutional rigidities", that were related to the expansion of the public sector and white collar private sector unions, because this trend caused also an extension of the solidaristic policy and consequently increasing intersectoral wage pressures and inflation. Frustration of the VF with bargaining of the SAF began in 1969 after conclusion of an unusually egalitarian agreement in the public sector that through intersectoral wage pressures lead to compression of wages also in other 
sectors, including the engineering industry. (Between 1970 and 1980 wage dispersion in area covered by the SAF and the LO decreased by about 54 percent, between $1973-1980$ in the state sector by 24 percent and in the municipal sector by 23 percent. Direct comparability is difficult, but there is a consensus, that wage levelling went further in the public sector than in the private one which also intensified conflicts over solidaristic wage policies within the private sector. However, in the early 1980s wage pressures in the public sector decreased, so a need to contain wage militancy in the public sector was no obstacle for decentralization (Iversen, 1999, p. 127, 131-132, 135)) This trend of stronger egalitarianization of wages lead to changes in wage structure in the engineering sector that was in the long term perspective unacceptable for the employers, but their growing dissatisfaction was due to their minority position within the SAF unheard. The VF strengthened its position in 1976 by way of electing Curt Nicolin from ASEA (one of the leading engineering corporations) as a chairman of the SAF. That caused change of its political course towards more radical and confrontation style against "the red wave" in the Swedish politics (especially issue of the wage earners fund proposal and economic democracy, but also for example expansion of the public sector). As Swenson (1993) put it, employers generally supported Nicolins' radical approach in sphere of managerial and investment control, but much less in distributional issues related to domination and particular interests of the export sector in collective bargaining. The VF was the strongest association within the SAF, but it has never had full domination within this organisation and during the post-war period its position became weaker among others because of growing power of the domestic and sheltered sector, increasing number of small domestic employers especially in the private service sector and recruiting strategies of the SAF focused on them. This development in combination with different interests of employers in other sectors (like retail or forestry sector) contributed to contradiction between interests of the VF and the bargaining strategy of the SAF as a whole. That also means that demands for decentralisation of the collective bargaining were independent on political mobilisation of the SAF and resulted from a power shift within the SAF in favour of the domestic employers.

Therefore, in 1983 changed the VF its strategy and concluded the separate contract with Metall that gradually lead to cancelling of the new rigidities, but the VF campaign became even more radical because of increasing demands for flexibility caused by the trend towards Post-Fordist production. Because of the impossibility to achieve desirable changes within the current institutional arrangements, the VF finally decided to dismantle the whole system of centralized bargaining. In 1989, the VF pressed the SAF to cancel its bargaining and statistical divisions; otherwise it would leave the SAF - 
apparently, at least for most of other employers, the idea of the SAF with a weak executive and with the VF was more acceptable than the idea of a divided SAF with a strong executive. However, the VF could have not afforded to carry out such an aggressive strategy without changes in the economic environment (i.e. internationalisation of their production and general changes in the global economy, see above), that caused a shift in bargaining power in favour of the export-oriented engineering corporations.

Their ally and crucial group in this process was Metall. The Post-Fordist methods of production contributed to blurring of lines between blue and white collar workers and in combination with expansion of the service sector it caused growing intersectoral wage rivalry, among others in case of the qualified blue collar workers (like metalworkers in engineering sector) who tended to compare their salaries with those of white collar workers. Individualisation of wages was also supported by the practice of wage drifts that undermined both moderation effects and ideological background of the solidaristic wage policy. (Swenson, Pontusson, 2000) Widened wage differentials were also probably caused by greater differences in profits among industries (inter alia result of a devaluation of SEK in 1982) that together with white-collar unions preference of low paid workers in centralized bargaining can explain changes in position of metalworkers unions (Erixon 2000: 33, 36)). The separate agreement in 1983 between the VF and Metall was signed by a new leadership of the metalworkers association, which was more loaded in favour of the qualified workers' demands for wage rise. However, Metall was not against the centralized bargaining system as such, but only against the solidaristic wage policy and supported restrictive monetary and fiscal policy as a new way of wage regulation (and thus prevention of inflation). They also supported increasing wage differentials between the export (especially engineering) and the other sectors. (Swenson, Pontusson, 2000)

\section{Consequences of the decentralization of collective wage bargaining in the 1990s}

The decentralization of collective wage bargaining weakened in some extent position of the central union's and employer's peak organizations and lowwage unions, but strengthened its sectoral organisations, especially in the export engineering sector. New role of the SAF, as a product of strategic initiative of the VF for achieving of changes in industrial and labor market policy, lied in lobbying, agenda setting and influencing of public opinion. (Johansson, 2000, 2005) Decentralization caused end of the direct participation of the LO in wage bargaining, but it still has potential to play a significant role in wage bargaining coordination carried out by its affiliated associations, so decentralization was not viewed as significant loss of influence by LO officials. 
Moreover, this role is in fact compatible with original intentions of the RehnMeidner model before centralized bargaining became a norm (Martin, 1992, p. 164-165) There are sometimes pressures for further decentralization towards bargaining on firm level (f.e. engineering employers in 1995). (Piazza, 2002, p. 104)

Changes in external environment like internationalization of production and investments (bringing new managerial ideals and practices not always compatible with the traditional Swedish industrial relations, stronger MNCs and weaker unions), Europeanisation (membership in the EU in 1995, more decision-making on the European level and generally growing dependence of the Swedish industry on non-national actors and institutions) created strong incentives to make a new Industrial agreement in 1997. These changed conditions as well as the third industrial revolution including expansion of services and small enterprises contributed to increasing variability of industrial relations which Sofia Murhem call "a new industrial relations regime" (Murhem, 2003). However there is still strong effect of institutional path dependency (corporatism, high union density or informal coordination of wage bargaining above sectoral level by the peak union and employer organizations).

Decline of the centralized collective wage bargaining was part of a wider process of changes in the Swedish political economy. Long-term commitment to Keynesian full employment policy (and expansion of the welfare state) might have contributed to oscillation of the degree of wage bagaining centralization in the 1980s. It was together with changes in the wage-formation process replaced by focus on price stability and balanced budgets, i.e. sectoral realignment for monetarist decentralization. (Iversen, 1999, p. 152, 164)

Decentralization of collective wage bargaining had also impact on labor movement unity with respect to tight relations between the LO and the Social democratic party. It contributed to decreasing capacity of the Social Democratic party to coordinate economic development of the country (f.e. maintain full employment), which was in the past one of the crucial aspects of tight relations between the LO and Social Democrats. (Martin, 1984) Difficulties or failing in realizing these goals might have contributed (and it actually did) to increasing policy differences between both parts of labor movement, weaken LO's influence within the Social democratic party and decrease its willingness and ability to mobilize electoral support for parties that depend on them (that means not only direct mobilization in election campaign, but also even more important role in political socialization). (Martin, 1992, p. 132-133) These risks manifested fully in the early 1990s in so called "war of roses" and colder relations between the LO and the Social democratic party. Nevertheless, the labor movement in Sweden has remained still strong in comparison with other countries, because it maintained and in the early $90 \mathrm{~s}$ it 
increased yet its organisational density (a peak was in 1996 with union coverage of 86 percent of workers in the private and public sector).

\section{Discussion and theoretical implications}

Changes in the global capitalist economy as well as Post-Fordism were similar for all advanced industrial countries, but such decentralisation took place only in Sweden. This fact requires further explanation.

Peter Swenson and Jonas Pontusson (2000) argues that the combination of comparatively extensive and powerful export engineering sector (leading to stronger pressures for flexibilization) and a comparatively big public sector (strongly influencing the private sector bargaining) together with this unique kind of centralisation and solidaristic wage policy based on the specific power coalition caused strong tensions between interest groups that had an impact on institutional structure and power alliances. These changes were carried out by internal actors, but their new institutional preferences were in considerable extent caused by exogenous factors.

Michael Wallerstein and Miriam Golden (2000) claim that obviously wage negotiation systems must reflect changes in the economic environment, but that does not mean necessarily decentralisation, because it depends on relations between and within unions and employers associations. In Sweden, the changes in political goals of the employers and their offensive against the centralized wage bargaining made it much more difficult to make a compromise.

As Sven Jochem (2004) points out, unlike Denmark, where the bourgeois parties had to make a coalition with social democrats and therefore corporatist institutions and welfare policy are based on cross-class party collaboration, politics in Sweden is divided into two class-based party blocs who make it more difficult to renegotiate corporatism.

Swenson (1993) maintains a position that collective wage bargaining (as one of the pillars of the Swedish model) was created as a product of a new tacit "cross-class coalition" between moderated factions of the Social democratic party and the LO and big export-oriented (especially engineering) business and it ended when policy and interests of the actors headed towards different directions (i.e. radicalisation of the social democratic policy and weakening position of the VF within the SAF that implied its incapability to advance its interests within current institutional arrangement). In this perspective, rise and fall of the centralized wage bargaining system is determined by rise and fall of this tacit "cross-class coalition" (it also coincided with rise and fall of Social Democracy).

Torben Iversen (1999) argues that regime change from Keynesian centralization to monetarist decentralization is caused by a power shift between different sectors of employers, unions and partisan government, especially in 
four respects: growing internationalization of production and capital market (constraining autonomy in macroeconomic policy), introducing of new and more flexible organizational forms and technologies, deindustrialization associated with rise of the public and private service sector that tend to lag in productivity and declining bargaining power of public sector and low-skill unions due to skill-biased shifts in labor demand and tighter fiscal constraints.

Anders S. Olsson (1990) claims that the Swedish model was designed for solving conflicts between labor and capital, but not to deal with serious conflicts between labor organizations (blue-collar and white collar unions as well as public and private sector unions). Rise of new actors with different interests and views on distributive justice contributed to the "wage carousel", when demands of one union pushed up demands of the other ones. For a long time, nobody was able to control the situation and fulfil its goals or to change the system which lead to high uncertainty and increasing conflict potential.

Both the institutionalisation and the dismantling of the centralized wage bargaining system was the product of certain cross-class compromise (or, as Swenson puts it, "cross-class coalitions"), with a crucial role of the exportengineering sector that has been dominating the Swedish economy during the last century and whose interests are shaped by global markets. That means that external dependency and the way of connection between the Swedish and the global economy are of substantial importance for internal power structure and thus via interaction between domestic actors influence, but not fully determinate shaping of socioeconomic institutions.

These findings rise the question what theoretical perspective is more suitable for explanation of the rise and decline of the centralized bargaining system in Sweden. In the literature, for analysis of corporatism and its complementarity to another socioeconomic institutions, often is some kind of institutionalist approach used (f.e. varieties of capitalism approach) that is strong in the field of institutions, their complementarity, path dependency and influence on behaviour of actors, but often neglects issues of ideology, power structure or links to the global economy. The power resources theory (f.e. work of Walter Korpi) is focused predominantly on power relations and especially on actors and their ability to mobilize power resources (including ideology) and to interact with other actors, but pays less attention to institutional structure and connection with the global economy. The dependency theory (especially Fernando Henrique Cardoso's version) and the world system theory (f.e. Immanuel Wallerstein) is concentrated on the global economy as well as its relation to local socioeconomic and political structures and development, but it is not much engaged in the analysis of individual actors' power mobilisation and of institutional structures. For more fruitful analysis and explanation of the problem of this study, therefore a complementary approach combining the 
strengths of these various perspectives should be applied and in this way it would be also possible to contribute to theoretical debates.

\section{BIBLIOGRAPHY}

ANDERSSON, T. - FREDRIKSSON, T. - SVENSSON, R.: Multinational Restructuring, Internationalization and Small Economies: The Swedish Case. London, New York: Routledge, 1996. 199 pp. ISBN 0-203-98238-X

ELSTER, J.: Tmel společnosti: studie sociálního řádu [The Cement of Society: A Study on Social Order] Praha: Academia, 2013, 357 pp. ISBN 978-80-200-22240

ERIXON, L.: ,A Swedish Economic Policy The Theory, Application and Validity of the Rehn-Meidner Model". [online], 2000. [cit. 2013-10-10], Dostupné na: http://www.ne.su.se/paper/wp00_13.pdf .

FOSTER, J. B. - MAGDOFF, F.: The Great Financial Crisis: Causes and Consequences. New York: Monthly Review Press, 2009. 160 pp. ISBN: 978-158367-184-9

GALENSON, W.: The World's Strongest Trade Unions: The Scandinavian Labor Movement. Westport: Greenwood Publishing Group, Inc., 1998. 161 pp. ISBN: 156720-183-0

HARVEY, D.: A Brief History of Neoliberalism. Oxford, New York: Oxford University Press, 2007, 274 pp. ISBN 0-19-928326-5

ICHEDA, S.: World Production. In: Hopkins, T. - Wallerstein, I. (eds.) The Age of Transition: Trajectory of the World System $1945-2025$. London, New Jersey, Zed Books, 1996, pp. 38-86.

IVERSEN, T: Contested Economic Institutions: The Politics of Macroeconomics and Wage Bargaining in Advanced Democracies. Cambridge: Cambridge University Press, 1999, 222 pp., ISBN 0-521-64226-4

JOHANSSON, J.: SAF och den svenska modellen: En studie av uppbrottet från förvaltningskorporatismen 1982 - 1991. [SAF and the Swedish Model: A Study of the Breaking with Corporatism in Government Agencies 1982-91] Uppsala: Acta Universitatis Upsaliensis, 2000, 248 pp., ISBN 91-554-4899-2

JOHANSSON, J.: Undermining Corporatism In: Öberg, P. - Svensson, T. (eds.) Power and Institutions in Industrial Relations Regimes: Political Science Perspectives on the Transition of the Swedish Model. Stockholm: National Institut for Working Life, 2005, pp. 77-106.

JOCHEM, S.: Nordic Corporatism and Welfare State Reforms: Denmark and Sweden Compared. In: Waarden, F. - Lehmbruch, G. (eds.): Renegotiating the Welfare State: Flexible Adjustment Through Corporatist Concertation. London, Routledge, 2004, pp. 114-141.

KORPI, W.: The Democratic Class Struggle. London, Boston: Routledge, Kegan Paul, 1983, pp. 277, ISBN 0-7100-9436-1

KORPI, W.: Power Resources and Employer-Centered Approaches in Explanations of Welfare States and Varieties of Capitalism: Protagonists, Consenters, and Antagonists. World Politics. vol. 58 , is. 02, 2006, pp. 167-206. 
LEWIN, L.: Ideology and Strategy: A Century of Swedish Politics. Cambridge: Cambridge University Press, 1988. 344 pp. ISBN 0-521-34330-5

LINDVALL, J. - SEBRING, J.: Policy Reform and the Decline of Corporatism in Sweden."West European Politics. vol. 28, no. 5, 2005, pp. 1057 - 1074.

MAGNUSSON, L.: An Economic History of Sweden. London, New York: Routledge, 2006. 305 pp. ISBN 0-203-75939-7

MARES, I.: Taxation, Wage Bargaining and Unemployment. Cambridge: Cambridge University Press, 2006. 266 pp. ISBN: 0-521-85742-2

MARTIN, A.: Trade Unions in Sweden: Strategic Responses to Change and Crisis. In: Gourevitch, P. - Martin, A. - Ross, G. (et al.): Unions and Economic Crisis: Britain, West Germany and Sweden. London, George Allen \& Unwin (Publishers) Ltd., 1984, pp. 191-359.

MARTIN, A.: Wage Bargaining and Swedish Politics. Stockholm: Fackföreningsrörelsens Institut för Ekonomisk Froskning, 1992, 179 pp., ISBN 91-8723242-1

MARTIN, A.: The Politics of Macroeconomic Policy and Wage Negotiation in Sweden. In: Iversen, T. - Pontusson, J. - Soskice, D. (eds.): Unions, Employers and Central Banks: Macroeconomic Coordination and Institutional Change in Social Market Economies. Cambridge: Cambridge University Press, 2000, pp. 232-264.

MEIDNER, R.: Why Did the Swedish Model Fail?. In: Miliband, R. - Panitsch, L. (eds.): Real Problems, False Solutions - Socialist Register 1993. London, Merlin Press, 1993, pp. 211-228.

MURHEM, S. - A New Industrial Relations Regime in the 1990s. Uppsala: Acta Universitatis Upsaliensis, 2003, 250 pp., ISBN 91-554-5726-6

OLSSON, A. S.: The Swedish Wage Negotiation System. Hants, Brookefield: Dartmouth Publishing Company Limited, 1991, 168 pp., ISBN 1-85521-203-X

PIAZZA, J. A.: Going Global: Unions and Globalization in the United States, Sweden and Germany. Lanham, Boulder, New York, Oxford: Lexington Books, 2002, 166 pp., ISBN 0-7391-0351-2

PONTUSSON, J.: Sweden. In: Kesselman, M. - Krieger, J. - Allen, C. S. (et al.): European Politics in Transition. Lexington [u. a.], Heath, 1987, pp. 451-549.

RYNER, M. J. Capitalist Restructuring, Globalisation and the Third Way: Lessons from the Swedish Model. London, New York: Routledge, 2006. 272 p. ISBN 0-20316491-1

STEPHENS, J. D.: The Scandinavian Welfare States: Achievements, Crisis, Prospects. In: Esping-Andersen, G. (ed.): Welfare States in Transition: National Adaptations in Global Economies. London, Sage, 1997, pp. 32-65.

SWENSON, P.: Bringing Capital Back In, or Social Democracy Reconsidered: Employer Power, Cross-Class Alliances, and Centralization of Industrial Relations in Denmark and Sweden'. World Politics. vol. 43, is. 4, 1991, pp. 513-544.

SWENSON, P.: The End of the Swedish Model in Light of its Beginnings: On the Role of Engeneering Employers and their Leaders. Discussion Paper FS I 93 - 303. Berlin: Wissenschaftzentrum Berlin für Sozialforschung, 1993. 55 p..

SWENSON, P. - PONTUSSON, J.: The Swedish Employer Offensive against Centralized Bargaining. In: Iversen, T. - Pontusson, J. - Soskice, D. (eds.): Unions, 
Employers and Central Banks: Macroeconomic Coordination and Institutional Change in Social Market Economies. Cambridge: Cambridge University Press, 2000, pp. 77-106.

TSAHOURAS, D.: Social Democracy in Sweden: The Threat from a Globalized World. London, New York: I.B. Tauris \& Co Ltd., 2008. 275 p. ISBN: 978-184511-786-3

WALlERSTEIN, M. - GOLDEN, M. 2000. Postwar Wage Setting in the Nordic Countries. In: Iversen, T. - Pontusson, J. - Soskice, D. (eds.): Unions, Employers and Central Banks: Macroeconomic Coordination and Institutional Change in Social Market Economies. Cambridge: Cambridge University Press, 2000, pp. 107137.

PhDr. Mgr. Karel Hanuš (1984) received a Master's degree in sociology and Latin American studies at the Faculty of Arts, Charles University. Since 2011, he has been studying sociology at the same faculty in full-time doctoral study program. He graduated one semester study fellowship at Universidad Autonóma de Madrid (2010), two semesters study-research fellowship at Ruprecht-Karls-Universität Heidelberg (2012 - 2013) and two months research fellowship at Uppsala Universitet (2013). He published articles for example in Historická sociologie/Historical Sociology or Politologická revue. Currently, he focuses on development of the Swedish welfare state and some issues in historical sociology.

PhDr. Mgr. Karel Hanuš Katedra sociologie Filosofická fakulta UK

Celetná 20

11642 Praha 1

Czech Republic hanusk@email.cz 
Appendix A: Swedish Governments and Prime Ministers 1932 - 1994

\begin{tabular}{|l|l|l|}
\hline & Prime minister & Parties in the Cabinet \\
\hline $1932-1936$ & Per-Albin Hansson & S \\
\hline $1936-1939$ & Per-Albin Hansson & S, A \\
\hline $1939-1945$ & Per-Albin Hansson & S, A, L, C \\
\hline $1945-1946$ & Per-Albin Hansson & S \\
\hline $1946-1951$ & Tage Erlander & S \\
\hline $1951-1957$ & Tage Erlander & S, A \\
\hline $1957-1969$ & Tage Erlander & S \\
\hline $1969-1976$ & Olof Palme & S \\
\hline $1976-1978$ & Thorbjörn Falldin & A, L, C \\
\hline $1978-1979$ & Ola Ullsten & L \\
\hline $1979-1981$ & Thorbjörn Falldin & A, L, C \\
\hline $1981-1982$ & Thorbjörn Falldin & A, L \\
\hline $1982-1986$ & Olof Palme & S \\
\hline $1986-1991$ & Ingvar Carlsson & S \\
\hline $1991-1994$ & Carl Bildt & C, L, A, CD \\
\hline
\end{tabular}

$(\mathrm{S}=$ Social democrats, $\mathrm{A}=$ Agrarians (Center Party since 1957), $\mathrm{L}=$ Liberals, $\mathrm{C}=$ Conservatives (since 1969 Moderate Party), $\mathrm{CD}=$ Christian Democrats)

Source: adapted from (Pontusson 1987: 468) 